は，現在までまだはっきりしていないが，頻運動の機 能力がその形態を瑕づくるとされている，咬筋の一部剥 離を行なって観察した対木（1950）によると，咬筋の作 用は，下颚骨の形態発宵之くに隅佮部の後方発育に及ぽ す影響が大であると報告した，私は今回，咬筋全層の完 全切除による, 大きな咀嚼機能衰失に伴う発育変化を詳 細に観察した。

材料としては, 日本産雑種犬の乳㐘列完成直後（生後 1.5〜2.0月）の仔犬72匹を実験に供した。

方法としては, 片側の 3 層よりなる咬筋の全部起始 部より停止部まで慎重かつ完全に切除した。

実験後飼育期間は 1 力月〜 7 カ月まで各段階にわけて 観察し，非実験側之対照検討した。令回は実験数の一部 についての報告である。

1）肉眼的な下顎枝の発学变化

a. 下顎枝の Masseter fossa の平坦化，つまり刘照 侧に比して骨質部が増築肥大し，とくに下顎孔部が 顕著である。

b. 下颚角突起, 関節突起の退縮.

c. その他，下顎枝頰側面は全般的に粗造感を呈し， ケースによっては多少の小凹凸あるいは，小孔の点 在が認められた。

2) 計測的な発育変化

a. 術後 7 カ月の 4 例における下顎体高, 下顎枝角, 下顎体角の計測值は表の上抢りである

\begin{tabular}{|c|c|c|c|c|c|}
\hline \multirow{2}{*}{ 計測部位 } & \multirow{2}{*}{$\begin{array}{l}\text { 左 } \\
\text { 不 } \\
\text { 側 }\end{array}$} & \multicolumn{4}{|c|}{ 実 験 番 号 } \\
\hline & & No. 37 & No. 40 & No. 49 & No. 31 \\
\hline \multirow{2}{*}{$\begin{array}{l}\text { 下顎体高 } \\
\text { (cm) }\end{array}$} & $\mathrm{L}$ & 5.41 & 6.58 & 6.22 & 6.25 \\
\hline & $\mathrm{R}$ & 3.60 & 5.47 & 4.58 & 3.53 \\
\hline \multirow{2}{*}{$\begin{array}{c}\text { 下顎枝角 } \\
\left({ }^{\circ} \theta\right)\end{array}$} & $\mathrm{L}$ & 116.3 & 116.5 & 115.0 & 118.0 \\
\hline & $\mathrm{R}$ & 113.3 & 113.5 & 108.5 & 113.0 \\
\hline \multirow{2}{*}{$\begin{array}{c}\text { 下顎体角 } \\
\left({ }^{\circ} \theta\right)\end{array}$} & $\mathrm{L}$ & 144.5 & 132.5 & 135.5 & 130.5 \\
\hline & $\mathbf{P}$ & 160.0 & 150.5 & 152.5 & 155.5 \\
\hline
\end{tabular}

(L；実験側)

b. 下顎骨全長のうち, if〜 $\mathrm{cl}$ は術後 3 力月以後にお いて0.18 0.60cm, if $\operatorname{goc}$ は 2 力月以後に打い て0.39〜1.72 cmの発青差が見られた。

筋突起の高さは, 術後 2 力月以後に求いて0.26〜0.76 cmの発育差が見られた。

肉節頭の長径は, 術後 1 力月以後において0.01〜0.51 cmの発育差が見られた。

\section{質 疑}

(1口外) 平 川

御実験の形態的変化には異議ないが，咬筋切除を行な った場合，開口障害が起るか。

応 答

(口 縕) 神 田

術後の開口障害は全く起らないとは断定できないがほ

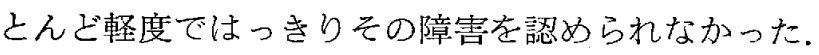

\section{6. う蝕発病率の年令的変異の研究}

(九幽大・簿) 上田茂 治

I 研究目的

從来，う蝕発病率の 報告の大部分は，小中学生が主 で，一部分の年令を用いた研究では，う蝕の発病状態を 十分に把握できないと考え，同一地域居住民の乳幼坚か ら高令者にいたる，う蝕発病状態について，年令的変動 を研究した。

II 対 象

対象は，北儿州として小含区郊外，カルスト高原平尾 台の北西, 東谷地区と, 東南行橋市椿市地区, 上五島之 して長崎県五島の上五島町地区住民，0才から95才まで である，北九州は男947名，女1096名，計 2043 名，上五 島は男929名，女1079名計2008名，合計4051である。

III 観察項目之力法

$\mathrm{dft}$ 率，DMFT率について観察し，地区間，男女 間，上下顎間などについて比較した。

IV 結 果

$\mathrm{dft}$ 率：両地区の男女とも下顎が上顎より高く，また 女の方が高い，両地区間の差はほとんごない。

$(\mathrm{ft} / \mathrm{dft})$ 率 : 男女之もに北九州の力方高く，男女間 の差は両地区とむにほと九どない．

DMFT 率：両地区の男女之委下顎が上顎より高く， また女の方が高い，地区間では女は五島が高く，男はほ とんど差がない。

（FT/DMFT）率：両地区之も女の方が高く，男 女ともに北九州の方が高い.

$(\mathrm{a}+\mathrm{t}+\mathrm{DMFT} / \mathrm{T})$ 率：男女間の差は，両地区之 あに女の方が高く．両地区間では男は上五島の方が高 く，女はわずかに上五島の方が高い。

\section{7. ヒトの歯の生歯と脱落の統計学的研究}

（九掬大・口衞）末 原 靖 弘

ヒトの崡の生䨑と脱落は性, 年令, 環境, 食生活, 気 象等に左右される。宮崎県の清武町に居住する1才より 
85才までの男 2122 人，女2993人，計 5115 人を対象として 調查を行ない，つぎのような結果をえた。

1. 男女別年令別乳歯現有平均歯数

男は1才に平均12.5本，2才に19.1本，4才に20.0本 である。文は 1 才に15.0本，3才に20.0本である。乳㐘 脱落は男女とも5才頃より始まり13才にはほとんど0上 なる，女が男より乳歯の生畨，脱落とも早い，

2. 男女別年命別永久歯平均生歯数

4 才に男は平均0.04本，女は平均0.02本で，15才には 男女とも平均27.7本である。男も女も15才までに28本の 永久䨑が生歯し, 各年令上も女が多い.

3. 男女別年令別永久歯平均啔失歯数

男女と屯10才代ではわずかで増令にともなって増加 し，80才代に男は平均20.2本，女か汗均 25.5 本である。 女が男上り多い。

4. 男女別上下顎左側の永久歯生歯年令々男女間の差 生菌年令は男女とも上颚は $6,1 ， 2 ， 4 ， 3 ， 5$ ， 7 下顎は $6 ， 1 ， 2 ， 3 ， 4 ， 5 ， 7$ の順に早く, 女が 男より早い.

5. 生菡年令の上, 下顎の差

男は右側の 1，2，3，5，6 上左側の 1，2，3， 6 , 女は左右側の 4,5 を除く各雨に有意の差があり, 下谔真が上顎より早い.

6. 生雨年令の左, 右側の差

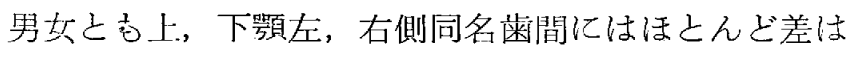
ない.

\section{7. 男女別左側永久料生㐘型百分比}

生㐘型を11型に分類した各年令の生歯型百分比は，上 下颚，男女之も $5 ， 6$ 才には 1 型，9，10才に 5 型，年 令の増すにつれて11型が多くなる。

\section{8. 養老院収容者のう菌の加療状態}

(九雨大・竹) 滝 口親 尚

福岡県内養老院42力所に居住の50才〜95才の男 835 人，女1185人，計 2020 人を対象として，う歯加療の実態 を年令之男妒間の比較をした，経験う歯のうち，D T, MT及び F T について生歯数に対する比率（\%)，また 各項目がDMFTに対する比率などを観察し，次のよう な結果を得た。

1. 生雪数に対し, MT, Denture T, DMFT, 打 よびFTは男女とも増令につれて増している，堌令につ 机ずかな減少は，DT, Metal crown T, 增令につれ 増減の少ないのは, Filling T, である。

2. DMFTに対し，増令につれ増率するのは，M
$T$, Denture T, MT $\rightarrow \mathrm{FT}$, 增令につれ減少するの は, DT, Metal crown T,FTで増減の少ないのは, Filling Tである.

3. F Tに対し, 增令につれ増率するのは, Denture $\mathrm{T}$, 減少するのは Metal crown, 増減のないのは Filling Tである.

4. MTに対し， MT $\rightarrow \mathrm{FT}$ は年令が増すにつれ增減 は著しくない。

5. 現在歯数に対し，Alu，Pyorrhoea T は男女と屯 増令につれて増率している。

\section{9. 某所受刑者う歯の加療状態}

(九茷大·口衛) ○鎌田政秀・村岡俊彦 某所受刑者のう歯の加療状態の実態を調查した成績の 一部を報告する。

対象：20〜75才の男331で，比較対照には福岡市成人 男女を用いた。

調査項目：各年令階級 別に現存 歯数, D T 数, MT 数, $\mathrm{MT} \rightarrow \mathrm{FT}$ 数, $\mathrm{MT}-(\mathrm{MT} \rightarrow \mathrm{FT})$ 数, 要治療菌 数, FT 数, DMFT数, 生歯数なごで, それらの各項 目の総雪数, 平均歯数を出し, 生歯数及び DMF T 数に 対する調查項目別の百分比之標準偏差を求めた。

成績：1. 生蒾数に対するう雬数の百分比

1) $\mathrm{DT} /$ 生歯数 $\%, \mathrm{MT} /$ 生歯数 $\%$ : 福岡市男<受刑 者<福岡市女, 2) $\mathrm{MT} \rightarrow \mathrm{FT} /$ 出歯数 $\%$ : 福岡市男 $\div$ 受刑者<福岡市女，3） $\mathrm{MT}-(\mathrm{MT} \rightarrow \mathrm{FT}) /$ 生菌数 : 福岡市男<受刑者 $>$ 福岡市女, 4) FT/生蒾数\%。 D MF T/生薁数 $\%$ : 福岡市男 > 受刑者 <福岡市女,

5）要治療歯/生崡数 \% : 福岡市男<受刑者 $\div$ 福岡市女

2. DMFT数に対するう歯数の百分比

1) DT /DMFT\% : 福岡市男<受刑者 $\div$ 福岡市 女, 2) $\mathrm{MT} \rightarrow \mathrm{FT} / \mathrm{DMFT} \%$ : 福岡市男<受刑者 <福岡市女, 3) $\mathrm{MT} / \mathrm{DMFT} \%, \mathrm{MT}-(\mathrm{MT} \rightarrow \mathrm{F}$ T) DMFT \%, 要治療蒾数/DMFT\%: 福 岡市男 $<$ 受 刑者>福岡市女，4）FT/DMFT \% : 福岡市男>受 刑者<福岡市女.

$$
\text { むす ず }
$$

受刑者のう歯の加療状態は概して福岡市男女に比べて わるいようで，それで，それらの原因については，今後 の調查によってあきらかにしたいと思う。

\section{0. 水平移動式断層撮影装置（TYPE HL-5）の精度 と拡大率及びボケについて}

(九料大. 1 補) 中 尾 文 則 